\title{
Foreldretvister for lagmannsrettene - fordeling av barn mellom mor og far
}

Kristin Skjørten

Kristin Skjørten er forsker I ved Nasjonalt kunnskapssenter om vold og traumatisk stress, og professor II ved Institutt for offentlig rett, Universitetet i Oslo.

krskjor@jus.uio.no

kristin.skjorten@nkvts.no

\section{Sammendrag}

Blir mødre favorisert i foreldretvister om bosted for barn? Dette spørsmålet skal belyses med utgangspunkt i et større antall lagmannsrettsdommer som strekker seg over en lengre tidsperiode. Jakten på kjønnede mønstre foregår langs to spor. For det første analyseres de argumentene som legges til grunn for valg av bosted. For det andre analyseres om sentrale kjennetegn ved dommene som ikke inngår i begrunnelsene for utfall, likevel kan avdekke kjønnede mønstre. Kort oppsummert viste det seg å være både kjønnede og ikke-kjønnede dimensjoner både i forhold til argumenter for utfallet i dommene og kjennetegn ved sakene.

Nøkkelord:

foreldretvister, bosted, utfall, kjønnede mønstre

\section{Innledning}

Et stadig tilbakevendende spørsmål i den offentlige debatten er om fedre blir diskriminert i foreldretvister om bosted og samvær, og interessegrupper for fedres rettigheter har hevdet at dagens lovgivning favoriserer mødre. ${ }^{1}$ Dette har ført til krav om å endre barneloven for å styrke fedres rettigheter. Stortinget ba i 2017 regjeringen om å

«initiere en gjennomgang av dommer avsagt i barnefordelingssaker, for å finne svar på i hvilken grad fedre ikke når frem i rettssystemet og om det er grunn til å senke terskelen for å sende foreldre tilbake til mekling». ${ }^{2}$

I tilskuddsbrevet til Nasjonalt kunnskapssenter om vold og traumatisk stress (NKVTS) ble NKVTS bedt av departementet om å initiere prosjektet om utfall i foreldretvister for lagmannsrettene, under det pågående forskningsprosjektet «Foreldretvister og barns

\footnotetext{
${ }^{1}$ Haugli, T. (2007), «Lov om barn og foreldre», Jussens Venner nr. 6. Vol. 42. Se også diverse medieoppslag med fremstilling om at barneloven favoriserer mødre, for eksempel: https://www.nrk.no/ytring/barnelovendiskriminerer-far-1.14348036 https://www.nettavisen.no/nyheter/nrk-brennpunkt-dokumentar-barn-og-fedre-trenger-ogsa-familie--oglikestillingspolitikk/3423687306.html

2 Prop 1. S (2018-2019) Barne- og likestillingsdepartementet, Vedtak nr. 494, 7. mars 2017, s. 28, og Innst. 195 L (2016-2017) Innstilling til Stortinget fra familie- og kulturkomiteen om Endringer i barnelova mv. (likestilt foreldreskap), s. 26.
} 
rettigheter». Barne-, ungdoms- og familiedirektoratet fikk i oppdrag sammen med Domstoladministrasjonen å se nærmere på hvordan familieverntjenesten og domstolene kan styrke samarbeidet i foreldretvister med høyt konfliktnivå, for at flere saker kan løses ved mekling. ${ }^{3}$

I denne artikkelen presenteres funn fra NKVTS-prosjektet om utfall i foreldretvister for lagmannsrettene om bosted for barn. I nyere lovforarbeider har begrepet 'foreldretvister' blitt tatt i bruk om saker etter barneloven, som alternativ til det etablerte begrepet 'barnefordeling'. Argumentene for den nye betegnelsen er å tydeliggjøre foreldrenes eierskap til konfliktene, samt å markere «at barn ikke er noe som er til fordeling». ${ }^{4}$ I denne artikkelen hvor temaet er spisset mot utfall i saken, som her er ensbetydende med hvem av foreldrene som får omsorgen for barna, mener jeg det er på sin plass både å benytte betegnelsen barnefordeling eller fordeling av barna i tillegg til begrepet 'foreldretvister'.

Hvordan fordeles barn mellom mødre og fedre, og avtegner det seg kjønnede mønstre bak utfallet i disse sakene? Artikkelen baseres på dommer som er registrert i Lovdata Pro. Denne databasen skal omfatte alle høyesteretts- og lagmannsrettsavgjørelser i foreldretvister. På disse domstolsnivåene kan vi derfor få et representativt bilde av utfall i avgjørelser om bosted for barn. Vi mangler dessverre en viktig brikke for å kunne uttale oss mer generelt om rettstilstanden, nemlig hvordan tingrettene dømmer i spørsmål om bosted for barn. En vesentlig grunn er at det ikke finnes noen samlet database for tingrettsavgjørelser. ${ }^{5} \AA$ fremskaffe oversikt over utfall av alle tingrettsavgjørelser i en gitt periode vil være svært ressurskrevende. Høsten 2019 ble det imidlertid besluttet i Stortinget at alle tingrettsavgjørelser også skal gjøres tilgjengelige på Lovdata, ${ }^{6}$ og Domstoladministrasjonen skal utrede hvordan dette kan gjøres. På lengre sikt vil det forhåpentligvis bli overkommelig å fremskaffe representative data også fra tingrettene.

Barneloven gir foreldrene avtalefrihet i spørsmål om bosted, samvær og foreldreansvar for barn. ${ }^{7}$ Er barnet under 16 år, må imidlertid foreldrene møte til mekling. ${ }^{8}$ Mer enn 20000 foreldrepar møter til mekling hvert år, og flesteparten kommer frem til en privat avtale. ${ }^{9} \mathrm{De}$ senere årene har det vært nærmere 2700 barnelovsaker for tingrettene i året. Av disse inngås

\footnotetext{
${ }^{3}$ Prop 1. S (2018-2019), Barne- og likestillingsdepartementet, s. 28.

${ }^{4}$ Prop. 85 L (2012-2013) Endringer i barnelova (barneperspektivet i foreldretvister), s. 5.

${ }^{5}$ Kun et tilfeldig utvalg tingrettsdommer publiseres i Lovdata Pro.

${ }^{6}$ https://www.aftenposten.no/norge/i/2GwmLG/dommer-blir-gratis-tilgjengelig-for-alle

${ }^{7}$ Lov 8. april $1981 \mathrm{nr} .7$ om barn og foreldre (barnelova, bl.).

8 Jf. ekteskapsloven $\S 26$ og barneloven $\S 51$.

${ }^{9}$ Barne-, likestillings- og inkluderingsdepartementet (2015), Høringsnotat. Forslag til endringer i barneloven for å fremme likestilt foreldreskap, s. 6.
} 
det ifølge Oxford Research rettsforlik i syv av ti saker. ${ }^{10}$ Resten av foreldretvistene avgjøres med dom. Av Domstolsadministrasjonens årsrapport for 2019 fremgår det at barnelovsaker utgjorde 19 prosent av alle tvistesaker. ${ }^{11}$

\section{Utviklingen i bosted for barn}

En fjerdedel av alle barn under 18 år har foreldre som ikke bor sammen. Statistisk sentralbyrå (SSB) har foretatt representative undersøkelser om bosted for disse barna både i 2002 og 2012. Følgende figur viser endringer i bostedsmønstre fra 2002 til 2012:

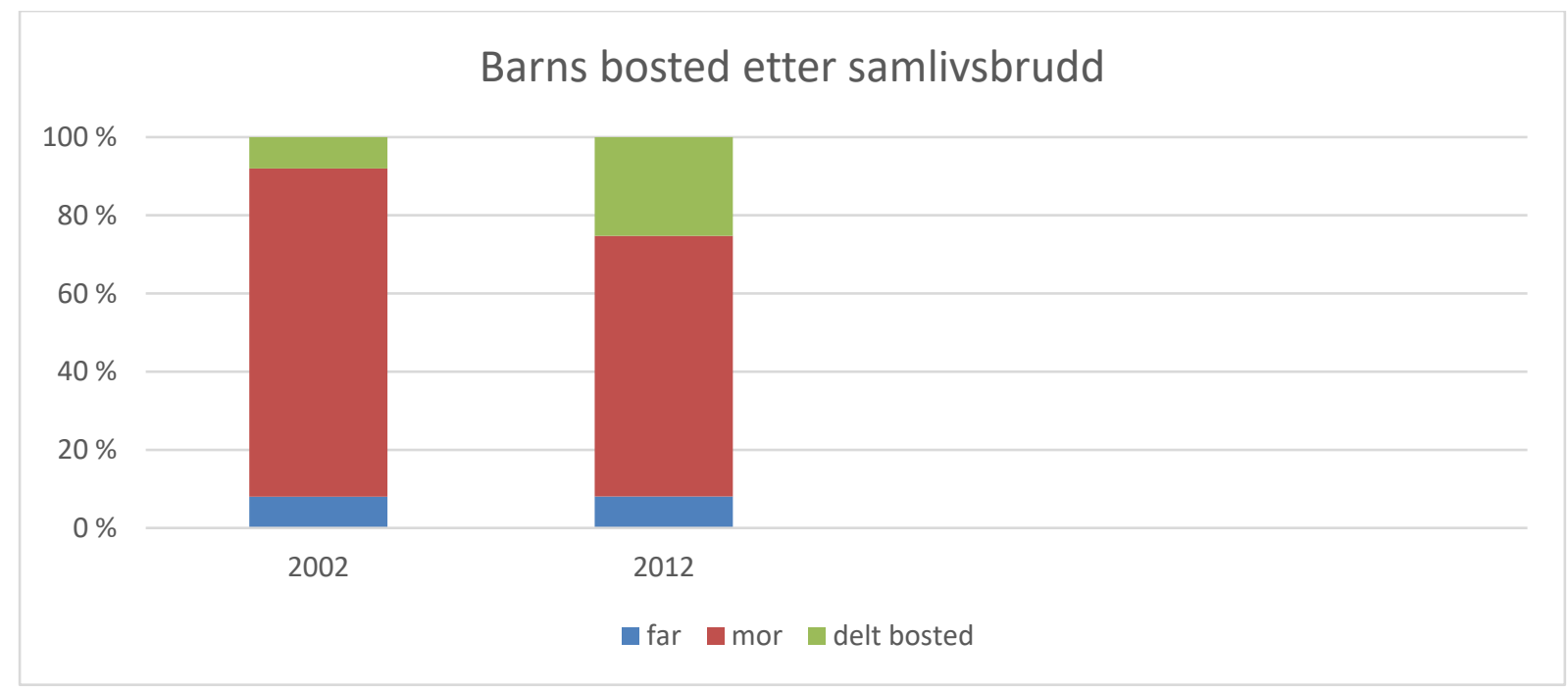

Ifølge SSB har det vært en $\varnothing$ kning i antallet barn med delt bosted, fra 8 prosent i 2002 til 25 prosent i 2012. I samme periode har det vært en nedgang i andelen barn som bor fast hos mor, fra 84 prosent til 66 prosent. Andelen barn som bor fast hos far, har holdt seg stabilt på 7-8 prosent. ${ }^{12}$ Disse tallene forteller i hovedsak om utfallet av private forhandlinger, fordi de fleste foreldre finner frem til en privat avtale. Når det gjelder samvær, viser SSBundersøkelsene en $\varnothing$ kning i omfanget fra 6,5 dager i måneden i 2002, til 8,6 dager i 2012. ${ }^{13}$ Økning i delt bosted og økning i omfanget av samvær når barnet bor fast hos en av foreldrene,

\footnotetext{
${ }^{10}$ Viblemo, T.E, Tobro, M., Knutsen, V.S., Olsen, L.O., Gleinsvik, A. \& Busch, R. (2016), «Domstolsbehandlingen av foreldretvister.» Rapport fra Oxford Research i samarbeid med Proba Samfunnsanalyse. https://www.regjeringen.no/contentassets/abeffa225ffb4eb29a57d5bdac67d5a9/kartleggingdomstolsbehandlingen-av-foreldretvister-oxford-research-2016-.pdf

${ }^{11}$ https://www.domstol.no/arsrapport-2019/

12 Lyngstad, J., Kitterød, R.H. \& Nymoen, E.H. (2014), Bosted og samvær 2002, 2004 og 2012. Endringer $i$ ansvar og omsorg for barna når mor og far bor hver for seg. Oslo: Statistisk sentralbyrå. Rapport 2/2014.

${ }^{13}$ Meld. St. 24 (2015-2016) Familien - ansvar, frihet og valgmuligheter. Barne- og familiedepartementet, s. 79. Se også Kitterød, R.H., Lidén, H., Wiik, K.A. \&Lyngstad, J. (2016), «Delt bosted for barn etter samlivsbrudd - en praksis for folk flest?» Sosiologisk tidsskrift, 24(1), s. 27-50.
} 
viser at begge foreldre nå er langt mer involvert i barnas oppvekst etter samlivsbrudd enn tidligere. Nå er det en stund siden siste SSB-undersøkelse om bosted og samvær ble gjennomført, og det er sannsynlig at bildet har endret seg noe i løpet av disse årene. SSB har nå fått i oppdrag å gjennomføre en ny undersøkelse som vil gi oppdatert kunnskap om dette. ${ }^{14}$

Som vi har sett, kommer de fleste foreldre frem til private avtaler om samvær og hvor barna skal bo. Med den frie avtaleretten er det ingen instans som overprøver avtaler der foreldre har blitt enige. Temaet for denne artikkelen er domstolenes vurderinger av bosted for barn i saker der foreldre ikke kommer frem til privat avtale, og en av dem velger å gå rettens vei. Nedenfor gis en oversikt over sentrale momenter for slike vurderinger som følger av lov og forarbeider.

\section{Rettslig utgangspunkt for vurderinger av bosted}

Ifølge barnekonvensjonen ${ }^{15}$ artikkel $3 \mathrm{nr} .1$ og Grunnloven ${ }^{16} \S 104$ andre ledd skal barnets beste legges til grunn i alle avgjørelser som berører barn. Videre fremgår det av barnekonvensjonen artikkel 9 at barn ikke skal adskilles fra foreldre dersom ikke hensynet til barnets beste gjør det nødvendig. Barneloven må være i samsvar med både Grunnloven og barnekonvensjonens bestemmelser. Etter barneloven $\S 48$ skal avgjørelser i foreldretvister først og fremst rette seg etter det som er best for barnet. Barnets beste skal dermed være det styrende hensynet i vurderingene. Ved lovendring i 2006 fikk bl. § 48 tilføyd et nytt annet ledd, hvor det fremgår at hensynet til å beskytte barn mot vold og overgrep skal inngå i disse vurderingene. Videre skal det foretas konkrete vurderinger av ulike andre momenter av betydning for barnets beste i hver enkelt sak. I bl. § 48 er det ikke spesifisert nærmere hvilke andre momenter som skal vurderes. Lovforarbeider og enkelte høyesterettsdommer som tar stilling til mer prinsipielle spørsmål, legger likevel føringer for vurderinger av barnets beste. I forarbeider til nyere lovendringer nevnes barnets følelsesmessige tilknytning, foreldrenes personlige egenskaper, hensynet til stabilitet, risiko ved miljøskifte, best mulig samlet foreldrekontakt og unngå å skille søsken. ${ }^{17}$ I eldre lovforarbeider er også hovedomsorg i samlivet fremhevet som aktuelt moment i vurderinger av barnets beste. ${ }^{18}$

I tillegg til bestemmelsen om barnets beste er også barns rett til å bli hørt nedfelt i barneloven. Ifølge $\S 31$ har barn rett til å uttale seg om spørsmålene saken gjelder, og barnets

\footnotetext{
${ }^{14}$ NOU 2020: 14 Ny barnelov. Til barnets beste, s. 199.

${ }^{15}$ FNs konvensjon om barnets rettigheter av 20. november 1989 (barnekonvensjonen, BK).

${ }^{16}$ Kongeriget Norges Grundlov av 17. mai 1814 (Grunnloven).

${ }^{17}$ Ot.prp. nr. 104 (2008-2009) Om lov om endringer i barnelova mv. (Flytting, delt bosted, samvær, vold mv.), s. 18.

18 Innst. O. nr. 30 (1980-1981) Innstilling fra Justiskomiteen om lov om barn og foreldre (barnelova), s. 14.
} 
$\emptyset$ nske skal gis økt vekt etter modenhet og alder. Retten til å bli hørt følger også av barnekonvensjonen art. 12 og Grunnloven $§ 104$.

Frem til 2010 måtte domstolene velge fast bosted hos en av foreldrene. Fra 2010 har barneloven $\S 36$ åpnet for adgang til å idømme delt bosted dersom det foreligger særlige grunner. I forarbeidene er de særlige grunnene nærmere presisert til blant annet at foreldrene ikke bor for langt fra hverandre, at konfliktnivået ikke er for høyt, og at barnet trives med delt bosted. ${ }^{19}$

Når det gjelder fastsetting av samvær, er utgangspunktet ifølge barneloven at samvær er til barnets beste. Om den forelderen barnet bor fast hos, hindrer gjennomføringen av samvær, kan den andre forelderen kreve ny avgjørelse om bosted for barnet. Samvær skal imidlertid nektes dersom retten finner at det ikke vil være til barnets beste. Videre fremhever $\S 43$ i barneloven noen momenter som bør vurderes ved fastsetting av samvær, som barnets alder, avstand mellom foreldrehjemmene, tilknytning til nærmiljøet, hensynet til best samlet foreldrekontakt og barnets eget syn på samvær. Domstolene kan fastsette alt fra at det ikke skal være samvær eller samvær med tilsyn, til at det skal være samvær opptil 50 prosent av tiden. Forskjellen mellom delt bosted og svært omfattende samvær er at den forelderen barnet bor fast hos, kan bestemme om barnet skal gå i barnehage, hvor i landet de skal bo, og andre større avgjørelser som angår barnets hverdag (bl. § 37). Ved delt bosted har begge rett til å være med på slike avgjørelser.

Det er verdt å merke seg at tidligere lovfestet fortrinnsrett for mor når det gjaldt omsorgen for små barn, den såkalte morspresumsjonen, ble opphevet med barneloven av 1981. Etter gjeldende lov er begge foreldre formelt likestilte, og loven gir ingen fortrinnsrett for noen av dem. ${ }^{20}$ Hva som er best for barn, kan variere med omstendighetene i de enkelte saker.

Det er barneloven av 1981 som er gjeldende rett for de dommene denne artikkelen handler om. I desember 2020 leverte Barnelovutvalget NOU 2020: 14 med forslag til ny barnelov. ${ }^{21}$ Det som kanskje vil ha størst betydning for avgjørelser om bosted, er forslaget om ikke å videreføre kravet om at det må foreligge særlige grunner for at domstolene skal kunne idømme delt bosted. Videre er det foreslått at den barnet bor fast hos, ikke lenger skal kunne avgjøre spørsmålet om flytting innenlands. Barnelovutvalget har imidlertid delt seg i et flertall

\footnotetext{
${ }^{19}$ Ot.prp.nr. 104 (2008-2009) s. 72-73.

${ }^{20}$ Bendiksen, L.R.L. og Haugli, T. (2018), Sentrale emner i barneretten, 3. utgave, Oslo: Universitetsforlaget, s. 118. Se også Ot.prp. nr. 104 (2008-2009) s. 1.

${ }^{21}$ NOU 2020: 14 Ny barnelov. Til barnets beste. Utredning fra et utvalg oppnevnt ved kongelig resolusjon 7. desember 2018. Avgitt til Barne- og familiedepartementet 4. desember 2020.
} 
og et mindretall med hensyn til begge disse spørsmålene, hvor mindretallet vil videreføre gjeldende rett. Uansett endringer som kommer med den nye barneloven, står det fremdeles fast at barnets beste skal være det styrende hensynet i foreldretvister, og Barnelovutvalget vil beholde dagens ordlyd hvor det heter at avgjørelser om blant annet bosted «skal først og fremst rette seg etter det som er best for barnet» (bl. § 48). Både etter gjeldende barnelov og forslaget til ny barnelov skal hensynet til barnets beste være «overordnet hensynet til ønsker og rettigheter for hver av foreldrene». ${ }^{22}$

\section{Metode}

Denne artikkelen bygger på et større datamateriale med 371 dommer i foreldretvister om bosted for lagmannsrettene fra fire tidsperioder mellom 1998 og 2015. Dommene er hentet fra Lovdata Pro, og utgjør samtlige dommer som ble avsagt i de valgte tidsperiodene. ${ }^{23}$ Den første perioden omfatter dommer fra 1998 til 2000, neste periode dommer fra 2006 til 1. juli 2007. Tredje periode omfatter dommer fra 2012, og fjerde periode dommer fra $2015 .{ }^{24} \mathrm{I}$ denne artikkelen presenteres utfallet $\mathrm{i}$ alle fire periodene for å gi et bilde av utviklingen over tid. I den mer detaljerte analysen hvor formålet er å avdekke eventuelle kjønnede mønstre som kan skjule seg bak utfallstallene, er dommene fra 2015 lagt til grunn. Tvisteloven ${ }^{25}$ stiller krav til utforming av dommer. Ifølge § 19-6 skal rettslige avgjørelser gi en fremstilling av saken, partenes anførsler og påstander, og rettens vurderinger og begrunnelse for dommen.

Lagmannsrettsdommer i foreldretvister er ganske omfattende tekster som inneholder mye informasjon. I Lovdata Pro er dommene avidentifisert. Jeg har kodet informasjon fra dommene i et omfattende kodeskjema og lagt dette inn i SPSS. ${ }^{26}$ Dataene er ikke egnet for avanserte statistiske analyser, og SPSS er kun benyttet for å sikre oversikt over fordeling av verdier på ulike variabler. Analysen har tatt utgangspunkt i frekvensfordeling for å identifisere hvilke variabler som pekte seg ut for mer inngående analyse. Det ble videre kjørt krysstabeller mellom aktuelle variabler for ytterligere å finne frem til ulike mønstre som burde analyseres nærmere. Tematisk analyse er så lagt til grunn for den videre gjennomgangen av dommene. ${ }^{27}$

\footnotetext{
22 NOU 2008: 9 Med barnet i fokus - en gjennomgang av barnelovens regler om foreldreansvar, bosted og samvær, s. 11.

${ }^{23}$ I Lovdata Pro er dommene avidentifisert.

${ }^{24}$ Tidsperiodene er valgt for å kunne studere eventuelle endringer i rettspraksis som følge av st $\emptyset$ rre endringer i barneloven, særlig når det gjelder barns rett til å bli hørt og retten til beskyttelse mot vold og overgrep. I tidligere publikasjoner har jeg sett nærmere på dommer før og etter lovendringer på disse områdene, og redegjort for endringer i rettspraksis.

${ }^{25}$ Lov om mekling og rettergang i sivile tvister (tvisteloven).

${ }^{26}$ Statistical Product and Service Solution (SPSS).

${ }^{27}$ Braun, V. \& Clarke, V. (2006), "Using thematic analysis in psychology», Qualitative Research in Psychology, Vol. 3(2), s. 77-101.
} 
Denne metoden hører inn under kvalitativ metode, og er hensiktsmessig når man ønsker å avdekke hovedmønstre i datamaterialet. Analyseprosessen kan skjematisk inndeles i tre faser, hvor den første omfatter gjennomlesning av dommene og koding av opplysninger. Neste fase er å legge disse opplysningene, nå i form av variabler med ulike verdier, inn på SPSS og deretter kjøre enkle statistiske analyser med frekvensfordeling på ulike variabler, og krysstabeller mellom variabler. Dette munner så ut i siste analysefase som består av kvalitativ analyse av dommene. For å identifisere eventuelle kjønnede mønstre av betydning for utfallet i sakene har jeg analysert argumenter og kjennetegn på tvers av dommene. I den avsluttende drøftingen trekkes trådene sammen.

\section{Utfall i foreldretvister i et lengre tidsperspektiv}

De senere årene har Høyesterett i gjennomsnitt hatt én barnelovsak til behandling i året. Disse sakene kan omhandle ulike spørsmål, og en gjennomgang utført av Bendiksen og Haugli viste at Høyesterett fra 1990 til 2010 har avsagt 12 dommer om fast bosted. I halvparten av disse dommene ble det bestemt at barna skulle bo fast hos far. I resten av sakene skulle barna bo hos mor. ${ }^{28}$ Etter 2010 har vi kun hatt én høyesterettsavgjørelse om fast bosted etter barneloven, HR-2020-1843-A. I denne dommen, som ble avsagt med dissens, ble det bestemt at barna skulle bo hos mor.

Følgende tabell viser utfallet i foreldretvistene om bosted for lagmannsrettene fra de fire tidsperiodene jeg har unders $\varnothing \mathrm{kt}$ :

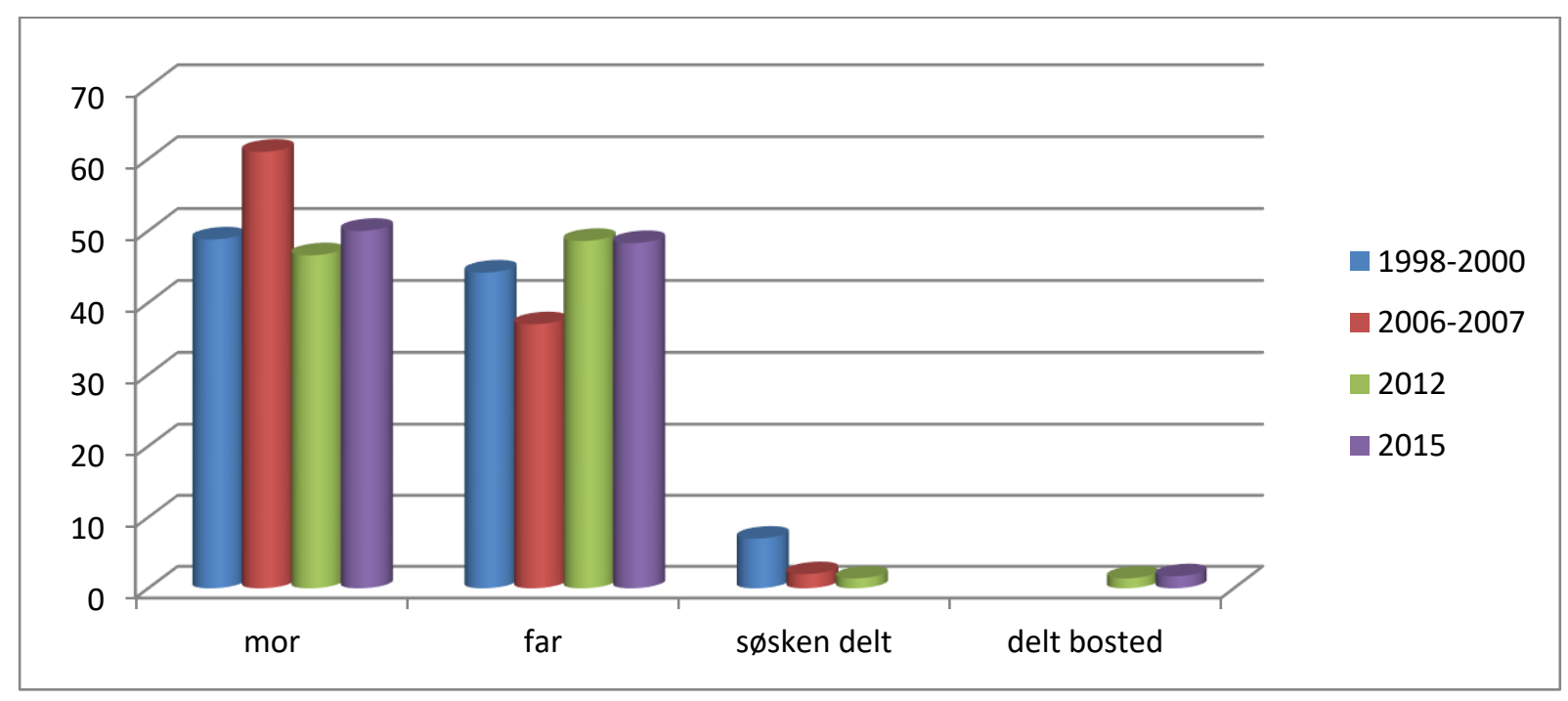

\footnotetext{
${ }^{28}$ Bendiksen, L.R.L. og Haugli, T. (2018) s. 122.
} 
Hovedinntrykket fra figuren ovenfor er at barn fordeles ganske jevnt mellom mor og far i foreldretvister for lagmannsrettene. I dommene for perioden 1998-2000 ( $\mathrm{N}=129)$ ble det fastsatt bosted hos mor i 48,8 prosent av sakene. I 44,2 prosent av sakene ble det bestemt at barna skulle bo hos far, og i 7 prosent av sakene fastsatte retten at søsken skulle deles mellom mor og far. I den neste perioden, fra 2006 til 1. juli 2007 (N=108), fikk mor medhold i at barna skulle bo fast hos henne i 61 prosent av sakene, og far fikk medhold i 37 prosent av sakene. I 2 prosent av sakene ble søsken delt mellom mor og far. Lovendring i 2010 hvor det ble det åpnet for en snever adgang til å idømme delt bosted, gjenspeiles i tallene fra 2012 $(\mathrm{N}=74)$, hvor mor fikk omsorgen i 46,6 prosent av sakene og far i 48,6 prosent. I 1,4 prosent av sakene ble søsken delt, og i like mange saker ble det fastsatt delt bosted. I 2015 (N=60) fikk mor omsorgen i 50 prosent av sakene, far i 48,3 prosent, og retten fastsatte delt bosted i 1,7 prosent av sakene.

Bildet av fordeling av barn mellom mor og far som fremkommer i disse periodene, kan suppleres med funn fra andre undersøkelser. Haugli fant i sin gjennomgang av 57 lagmannsrettsdommer fra 2002 at barna skulle bo fast hos far i 58 prosent av sakene, og hos mor i 40 prosent av sakene. I én av sakene ble søsken delt mellom foreldrene. ${ }^{29}$ I Martinsens gjennomgang av 23 lagmannsrettsdommer fra 2011 fant hun at mor fikk omsorgen i 52 prosent av sakene, i én sak ble det idømt delt fast bosted, og i resten av sakene ble det fastsatt at barna skulle bo fast hos far. ${ }^{30}$ Dybfest, som i sin masteravhandling blant annet så på utfallet i 63 foreldretvister for lagmannsrettene fra 2017 og 2018, fant at barna fikk fast bosted hos mor i 59 prosent av sakene, hos far i 36 prosent, og i resten av sakene ble det fastsatt delt bosted. ${ }^{31}$

Supplering av mine data med funn fra andre unders $\varnothing$ kelser gir informasjon om utfallet i foreldretvister for lagmannsrettene for omtrent halvparten av årene fra 1998 til 2018. Hovedbildet er en ganske jevn fordeling av barna mellom far og mor over tid, men det er verdt å merke seg skjevdeling enten i favør av mor eller far i noen av periodene. Det kan dermed ikke utelukkes at det også er skjevdeling i de tidsperiodene vi ikke har opplysninger om. Med dette forbeholdet bør det likevel kunne konkluderes med at både fedre og mødre har

\footnotetext{
${ }^{29}$ Haugli, T. (2007).

${ }^{30}$ Martinsen, L.J. (2012), Barnets beste ved fastsettelse av fast bosted for barn. En analyse av lagmannsrettspraksis fra 2011, masteroppgave i rettsvitenskap, Universitetet i Troms $\varnothing$, Det juridiske fakultet, våren 2012. Se også Martinsen, L.J. (2013), «Barnets beste ved fastsettelse av fast bosted for barn», Tidsskrift for familierett, arverett og barnevernrettslige spørsmål, nr. 1, 2013.

${ }^{31}$ Dybfest, H.E. (2019), Momenter i foreldretvister om fast bosted for barn, og vektingen av disse. Masteravhandling i rettsvitenskap, Juridisk fakultet, Universitetet i Oslo, våren 2019. https://www.duo.uio.no/handle/10852/70022
} 
muligheter til å vinne frem med sine påstander om at barna skal bo hos dem når foreldretvister står for lagmannsrettene.

I 2015 ble det avsagt dom om fast bosted for barn i 60 foreldretvister for lagmannsrettene. I den videre analysen legges disse dommene til grunn, for å se om det kan ligge noen kjønnede mønstre bak den jevne fordelingen av barn mellom mor og far.

\section{På jakt etter kjønnede mønstre - dommer fra 2015}

Kjønnsperspektiver i forskning kan dreie seg om å avdekke systematiske ulikheter i fordeling mellom kvinner og menn, og identifisere kulturelt skapte normer og forventninger som kan forklare dette. ${ }^{32}$ I denne artikkelen er temaet eventuelle kjønnede mønstre i rettens vurderinger av fedre og mødre ved fastsetting av bosted for barn. I foreldretvister skal barnets beste legges til grunn, og relevante momenter i rettens vurderinger kan være alt fra personlige egenskaper knyttet til foreldrenes omsorgsevne, til ytre omstendigheter som har betydning i disse vurderingene. I dommene benyttes gjerne betegnelsen 'omsorgsevne' om foreldres personlige egenskaper som omsorgsperson, og 'omsorgssituasjon' for en mer samlet vurdering både av personlige egenskaper og andre omstendigheter som anses å ha betydning i vurderingene. Jeg har valgt å bruke samme betegnelser.

En variabel i kodeskjemaet var om foreldrenes kjønn ble brukt som argument i lagmannsrettenes vurderinger av bosted for barn. Som nevnt ble morspresumsjonen fjernet med barneloven av 1981. Fra da skulle ikke lenger mødre ha fortrinnsrett til de yngste barna i saker hvor begge foreldre var skikket til omsorgen. Dette ser ut til å ha blitt fulgt opp i rettspraksis, og allerede kort tid etter at denne barneloven trådte i kraft, var mødres fortrinnsrett forsvunnet som begrunnelse for utfallet i foreldretvister. ${ }^{33}$ Foreldres kjønn har imidlertid også kunnet gjøres relevant på en annen måte. I foreldretvister noen tiår tilbake var det ikke uvanlig at foreldres kjønn ble løftet frem ved å vise til barnets behov for kjønnsidentitet. ${ }^{34}$ Undersøkelser viser imidlertid at hensynet til kjønnsidentitet er et moment som har blitt vesentlig svekket de senere årene, ${ }^{35}$ og det inngår ikke lenger blant de momenter som løftes frem som relevante for «barnets beste»-vurderinger i lovforarbeider. ${ }^{36} \mathrm{Nå}$ argumenteres det sjelden med at gutter har behov for å bo hos far og jenter hos mor for å

\footnotetext{
${ }^{32}$ Se Korsvik, T.R. og Rustad, L.M. (2018), «Hva er kjønnsperspektiver i forskning?», kjønnsforskning.no http://kjonnsforskning.no/sites/default/files/hva er kjonnsperspektiver i forskning rogg korsvik.pdf

${ }^{33}$ Sandberg, K. (1990), Barnets beste. Om barnefordeling, rettspraksis og rettferdighet, Oslo: Ad Notam; Skjørten, K. (2005), Samlivsbrudd og barnefordeling, Oslo: Gyldendal Akademisk.

${ }^{34}$ Smith, L. (1980), Foreldremyndighet og barnerett, Oslo: Universitetsforlaget.

${ }^{35}$ Sandberg, K. (1990); Skjørten, K. (2005); Ot.prp. nr. 104 (2008-2009).

${ }^{36}$ Ot.prp. nr. 104 (2008-2009).
} 
utvikle sin kjønnsidentitet. ${ }^{37}$ I 2015 ble ikke foreldres kjønn vektlagt under rettens vurdering av bosted i noen av dommene. Dette betyr at for å avdekke eventuelle kjønnede mønstre i domstolenes vurderinger av bosted for barn må man se bak den eksplisitte argumentasjonen.

Ganske jevn fordeling av barn mellom foreldre når sakene står for lagmannsrettene, kan selvfølgelig skjule kjønnsdiskriminering. ${ }^{38}$ Om det for eksempel er slik at majoriteten av fedrene i disse sakene har vesentlig bedre omsorgsevne enn mødrene, vil en ganske jevn fordeling av barna likevel kunne skjule en kjønnet favorisering, hvor det skal langt mer til for at far får omsorgen enn mor. Det er ingen enkel manøver å finne frem til eventuelle kjønnede mønstre som kan skjule seg bak den jevne fordelingen av barn mellom mor og far. Tilnærmingen jeg har valgt, er først å se å se på de argumentene som anføres som begrunnelser for utfallet. Deretter vil jeg løfte frem noen sentrale kjennetegn ved dommene som ikke inngår i begrunnelser for utfallet, men som kanskje likevel kan gi innsikt i eventuelle kjønnede mønstre. Avslutningsvis trekkes trådene sammen med en sammenfattende drøfting av mønstrene som fremtrer i analysen av argumenter og kjennetegn.

\section{Sentrale momenter i dommene}

I barneloven presiseres det at barnets beste skal legges til grunn i vurderingene, og at barn har rett til å bli hørt og rett til beskyttelse mot vold og overgrep. Momenter som fremheves i forarbeider som aktuelle i barnets beste-vurderinger, er risiko ved miljøskifte, personlige egenskaper hos foreldrene, stabilitet og forutsigbarhet, best samlet foreldrekontakt, barnets tilknytning til mor og far, hensynet til ikke å splitte søsken, og hovedomsorg i samlivet.

I 2015 var det ingen saker hvor søsken ble delt mellom foreldre. Vi skal derfor se på de øvrige momentene som ble vektlagt i 2015, på jakt etter eventuelle kjønnede mønstre. Utfallet i dommen kan enten begrunnes med ett avgjørende moment, eller baseres på flere aktuelle momenter i saken. I majoriteten av dommene fra 2015 ble avgjørelsene truffet på grunnlag av flere momenter. Mange av momentene som regnes som sentrale i barnets bestevurderinger, er imidlertid ikke klart adskilt fra hverandre. For eksempel kan barnets tilknytning være av betydning i rettens vurdering av risiko ved miljøskifte, og følelsesmessig tilknytning kan ha avgjørende betydning for barnets ønske om bosted hos mor eller far. Jeg har likevel valgt å behandle de ulike momentene separat, for så å trekke trådene sammen. Barnas ønsker Ifølge barneloven $\S 31$ har barn rett til å uttale seg i foreldretvister, og det skal legges vekt på deres synspunkter ut fra modenhet og alder. Denne retten innebærer ikke plikt til å uttale seg.

\footnotetext{
${ }^{37}$ Dybfest, H.E. (2019).

${ }^{38}$ Haugli, T. (2007).
} 
Barn skal gis anledning til å si sin mening dersom de ønsker det. Retten til å bli hørt er absolutt fra fylte syv år, men også yngre barn skal få anledning til å uttale seg om de ønsker det. Fra tolv år skal det legges stor vekt på barnets mening. Forskning har vist at domstolene i $\varnothing$ kende grad vektlegger barnas $\varnothing$ nsker i vurderinger om bosted og samvær. ${ }^{39}$

Hvilken betydning har så barnas ønsker om bosted for utfallet i sakene? I 2015 var det bare noen få barn under syv år som ble hørt om bostedsspørsmålet. For barn fra syv år og oppover ble flesteparten hørt. I den videre fremstillingen skal vi se nærmere på forholdet mellom barnas ønsker og utfall for de barna som var syv år eller eldre, fordi barnas innflytelse på utfallet $\varnothing$ ker med alderen. Litt over halvparten av sakene omfattet barn fra syv år og oppover, og i to tredjedeler av disse sakene fremmet barna klare ønsker om å bo hos den ene av foreldrene. ${ }^{40}$ Halvparten av disse barna $\varnothing$ nsket å bo hos far, og halvparten hos mor. Dommen ble i samsvar med barnas ønsker i de fleste av disse sakene. I de få sakene hvor utfallet gikk mot barnas ønsker, var det like ofte i favør av far som i favør av mor.

Med $\varnothing \mathrm{kt}$ vektlegging av barnas $\emptyset$ nsker i foreldretvister er dette utvilsomt et moment som bør tas med i betraktning når søkelyset rettes mot å forstå utfallet i sakene. I 2015 ser det ut til at barnas ønsker kan bidra til å forklare den jevne fordelingen mellom mor og far.

\section{Risiko ved miljøskifte}

I foreldretvister drøfter retten ofte om et skifte av barnets bosted vil innebære en belastning for barnet. Disse vurderingene kan både omhandle risiko ved et skifte av nåværende omsorgsperson og risiko ved skifte av bomiljø. Med bomiljø siktes det gjerne til venner, skole, barnehage og fritidsaktiviteter. I saker der dette hensynet blir utslagsgivende, finner retten at det er best for barnet å opprettholde den eksisterende omsorgssituasjonen. Dette momentet har over tid stått sterkt i rettspraksis om bosted for barn. ${ }^{41}$ I dommene fra $2015 \mathrm{er}$ også risiko ved miljøskifte det momentet som oftest inngår i begrunnelsene for utfallet $\mathrm{i}$ sakene. I nesten to tredjedeler av dommene inngår dette argumentet i begrunnelsen for valg av fast bosted, ofte i kombinasjon med andre momenter som hovedomsorg i samlivet, barnets tilknytning, barnets ønske, foreldres personlige egenskaper, best samlet foreldrekontakt og hensynet til stabilitet. I et par av dommene var risiko ved miljøskiftet det avgjørende

\footnotetext{
${ }^{39}$ Skjørten, K. (2013), "Children's voices in Norwegian Custody Cases», International Journal of Law, Policy and the Family 27 (3), s. 289-110; Skjørten, K. \& Sandberg, K. (2019), «Children's Participation in Family Law Proceedings»; Langford, M., Skivenes, M. \& Søvig, K.H. (eds.) (2019), Children's Rights in Norway. An Implementation Paradox? Oslo: Universitetsforlaget.

40 I de øvrige sakene valgte ikke barna mellom foreldrene, enten ved å uttrykke at de hadde det like bra hos begge foreldrene, eller at de ønsket delt bosted. I et par saker hadde søsken forskjellige ønsker om bosted. ${ }^{41}$ Skjørten, K. (2005); Haugli, T. (2007).
} 
argumentet i saken. Det er en klar overvekt av saker der mor får omsorgen, hvor dette momentet legges til grunn. I flere av disse sakene legges det i tillegg vekt på barnets følelsesmessige tilknytning, og at mor har hatt hovedomsorgen for barnet i samlivet. Går vi til partenes argumenter, er hovedbildet at den av foreldrene som har barnet boende hos seg, argumenterer med risiko ved miljøskifte eller status quo. Sistnevnte innebærer at om partene ellers stiller likt, må det vises til en fordel for barnet ved å flytte bosted. Motparten argumenterer gjerne med at et miljøskifte ikke vil innebære noe problem.

\section{Barnets følelsesmessige tilknytning}

Momentet om barnets tilknytning til hver av foreldrene får gjerne størst vekt når det gjelder de yngre barna. For de eldre barna er deres uttrykte ønsker mer sentrale i vurderingene. Mitt inntrykk er at retten ofte nøyer seg med å uttale at barna har god tilknytning til begge foreldrene. Er tilknytningen tilfredsstillende, går som regel dommerne ikke inn i vurderinger av mindre forskjeller i tilknytning til mor og far. ${ }^{42}$ I 2015 kommenterte retten barnas tilknytning i litt over halvparten av sakene. I omtrent halvparten av disse sakene igjen la retten til grunn at barna hadde god tilknytning til begge foreldrene. I de $\varnothing v$ rige sakene mente retten langt oftere at barna var mer knyttet til mor enn til far, og utfallet ble hovedsakelig i samsvar med barnets følelsesmessige tilknytning. Når retten først mener barna har sterkest tilknytning til den ene av foreldrene, får dette betydning for utfallet. Momentet inngikk ofte i en sammensatt argumentasjon hvor retten også la vekt på momenter som risiko ved miljøskifte, personlige egenskaper hos foreldrene, best samlet foreldrekontakt, og hovedomsorg for barnet i samlivet. Når mor fikk omsorgen, var risiko ved miljøskifte og hovedomsorg i samlivet oftest kombinert med momentet om barnets tilknytning.

I min tidligere unders $\varnothing$ kelse av lagmannsrettsdommer fra 1998 til 2000 fant jeg at barnas følelsesmessige tilknytning i hovedsak var et mødreargument. Majoriteten av mødrene hevdet at barna var mest knyttet til dem, mens få fedre hevdet det samme. ${ }^{43}$ Fremdeles er barnas følelsesmessige tilknytning i hovedsak et mødreargument, og kun fire fedre hevdet i 2015-dommene at barnet var mest knyttet til dem. Dobbelt så mange mente imidlertid at barna var like mye knyttet til begge. Blant mødrene var det nesten halvparten som argumenterte med at barna var mest knyttet til dem, og bare to som mente barna var like mye knyttet til begge foreldrene.

\footnotetext{
${ }^{42}$ Skjørten, K. (2005). Se også Dybfest, H.E. (2019).

${ }^{43}$ Skjørten, K. (2005).
} 


\section{Hovedomsorg i samlivet}

I forarbeidene til barneloven av 1981 uttalte justiskomiteen i tilknytning til opphevelsen av morspresumsjonen at hvem som har hatt hovedomsorg for barna, bør tillegges betydelig vekt $\mathrm{i}$ vurderinger av barnets beste for de minste barna, med avtagende vekt frem mot skolealder. ${ }^{44}$ Dette momentet svekkes jo lengre tid det går fra samlivsbrudd, og kan nok ha større betydning for utfallet når saken står for tingretten enn for lagmannsretten. Om hovedomsorgen skifter fra den ene parten til den andre etter samlivsbrudd, vil momentet bli ytterligere svekket, fordi omsorgssituasjonen etter samlivsbrudd kan bli et viktig moment $\mathrm{i}$ saken. Nesten halvparten av mødrene fremmet likevel momentet om hovedomsorg i samlivet i sin favør, mot kun to av fedrene. Dette momentet fremstår helt klart som et mødreargument. Om momentet legges til grunn for utfallet, er imidlertid en annen sak. I 15 prosent av dommene inngår momentet i begrunnelsene, oftest sammen med risiko ved miljøskifte og barnets tilknytning. I disse dommene får mor omsorgen for barna, og hun har hatt hovedomsorg både før og etter samlivsbrudd.

\section{Best samlet foreldrekontakt}

I saker etter barneloven er utgangspunktet for vurderinger av samvær at det er til barnets beste å ha god kontakt med begge foreldrene etter et samlivsbrudd. Hvem av foreldrene som best kan sikre barnet kontakt med den andre forelderen, kan derfor også være relevant $\mathrm{i}$ bostedsvurderingene. ${ }^{45}$ I 2015 mente dommerne i en fjerdedel av sakene at far best kunne ivareta barnets kontakt med den andre forelderen, og i flesteparten av disse sakene fikk fedrene omsorgen for barna. I kun én av ti saker mente retten at mor best kunne sikre barnet kontakt med far, og her fikk mor i hovedsak omsorgen. Videre mente retten at begge parter stilte likt i 12 prosent av sakene. Her fikk far omsorgen i flesteparten av sakene. Mor fikk omsorgen i én sak, og retten fastsatte delt bosted i den siste av disse sakene. Ser vi på partenes argumenter, var det flere fedre enn mødre som fremmet dette momentet i sin favør. Momentet fremstår som et fedreargument, og retten vektlegger dette momentet i favør av flere fedre enn mødre. Øvrige momenter som ble lagt til grunn i disse sakene, var risiko ved miljøskifte, barnas $\emptyset n$ sker, hovedomsorg i samlivet, barnets tilknytning, personlige egenskaper og hensynet til

\footnotetext{
${ }^{44}$ Innst. O. nr. 30 (1980-1981) s. 14.

${ }^{45}$ Som redegjort for under presentasjonen av rettslig utgangspunkt for vurderinger om bosted kan ifølge $\S 43 \mathrm{i}$ barneloven en forelder som nektes samvær, kreve ny avgjørelse om foreldreansvar og bosted for barn. Mitt valg hvor momentet om best mulig samlet foreldrekontakt er fremstilt som ulovfestet moment, beror på at dette hensynet omfatter mer enn hindring av samvær når det legges vekt på i avgjørelsene. Det trenger med andre ord ikke å ha funnet sted såkalt samværssabotasje for at dette hensynet vektlegges.
} 
stabilitet. Når momentet gikk i favør av far, var de mest sentrale øvrige momenter som begrunnet utfallet, hensynet til stabilitet og personlige egenskaper.

\section{Hensynet til stabilitet}

Med stabile forhold siktes det ofte til ytre omstendigheter ved omsorgssituasjonen. Gjentatte flyttinger, arbeidssituasjon som kan begrense omsorgskapasiteten, og stadig nye partnere vurderes negativt. Også partenes nettverk av familie og venner kan få betydning i vurderinger av stabilitet. Manglende nettverk eller venner som vanker i belastede miljøer, vil kunne indikere en ustabil omsorgssituasjon. Hensynet til stabilitet ble vektlagt i nesten en tredjedel av dommene fra 2015, og langt oftere i favør av far enn mor. Når far fikk omsorgen, var dette momentet ofte kombinert med hensynet til best samlet foreldrekontakt, personlige egenskaper og barnets $\emptyset$ nske. I sakene hvor mor fikk omsorgen, ble dette momentet gjerne kombinert med risiko ved miljøskifte og personlige egenskaper.

\section{Personlige egenskaper}

Foreldrenes egnethet som omsorgspersoner har over lang tid vært et sentralt moment $\mathrm{i}$ vurderinger av barnets beste. Momentet kan vise til både positive og negative trekk ved foreldres omsorgsevne, og ble vektlagt i over en tredjedel av sakene, like ofte i favør av far som mor. Momentet sammenstilles ofte med andre argumenter, som risiko ved miljøskifte, barnets tilknytning, hensynet til stabilitet, best samlet foreldrekontakt og barnets ønske. Hensynet til stabilitet og best samlet foreldrekontakt inngikk oftere i begrunnelsene når far fikk omsorgen enn når retten besluttet at barna skulle bo hos mor.

Nå foretar som regel ikke dommerne noen finjustert vurdering av partenes omsorgsevne, og det er sjelden de mener at en av partene er uegnet som omsorgsperson. Kommer retten frem til at det ikke skal være samvær, eller at samværet skal foregå med beskyttet tilsyn, hefter det imidlertid ofte alvorlige svakheter ved foreldres omsorgsevne. Det kan derfor være interessant å se nærmere på utfallet i saker der dette var aktuelt. Ifølge barneloven har foreldre og barn rett til samvær. Unntaket er der retten finner at samvær ikke er til barnets beste. ${ }^{46}$ I 2015 fastsatte retten i to av sakene at det ikke skulle være samvær. I begge saker var det far som ble nektet samvær. Også fastsetting av samvær med beskyttet tilsyn kan gi en indikator på omsorgsevne hos foreldre. Denne formen for tilsyn kan anvendes i saker der det hefter problematikk knyttet til vold, rus og psykiske problemer ved en av foreldrene, og retten likevel mener at et svært begrenset og overvåket samvær vil være til

\footnotetext{
${ }^{46}$ Barneloven $\S 43$ første ledd tredje punktum.
} 
barnets beste. ${ }^{47}$ I 2015 ble det fastsatt samvær med beskyttet tilsyn i seks saker, fordelt jevnt mellom mor og far. Om vi bruker sakene hvor det ble fastsatt beskyttet tilsyn eller at det ikke skulle være samvær, som indikator på foreldres omsorgsevne, fant retten problematiske sider ved en av foreldrenes omsorgsevne i åtte saker, fordelt på fem fedre og tre mødre.

Hovedbildet som tegnes av hvilken betydning momentet om personlige egenskaper har for utfallet i saken, viser imidlertid at dette momentet like ofte gikk i favør av far som i favør av mor. Dette momentet ser dermed ut til å støtte opp under den jevne fordelingen av barna mellom mødre og fedre i 2015.

\section{Kjennetegn ved sakene}

Vi skal nå se nærmere på noen viktige kjennetegn ved dommene for om mulig å identifisere kjønnede mønstre. De utvalgte kjennetegnene er hvem av partene som anket saken, barnas alder, kjønn og antallet barn som omfattes av saken. Dette blir en annen vei inn i problemstillingen fordi disse kjennetegnene ved sakene ikke inngår som argumenter for utfall.

\section{Hvem anker saken?}

Den av partene som anker saken til lagmannsretten, har tapt spørsmålet om bosted når saken sto for tingretten. Med utgangspunkt i lagmannsrettsavgjørelsene kan vi dermed få kunnskap om hvordan to rettsinstanser har vurdert fars og mors omsorgssituasjon. I 2015 viste det seg at fedre og mødre var den ankende part i like mange saker hva angikk spørsmålet om bosted. Dette forteller at tingrettene har vurdert mødre som best egnet til å ha omsorgen like ofte som fedre i de sakene som ble anket.

Hva skjer så med utfallet når saken står for lagmannsretten? Blir dommen stadfestet, eller har lagmannsretten et annet syn på mors og fars omsorgssituasjon? Om dommene fra tingrettene ikke blir stadfestet, er det noen systematiske skjevheter med hensyn til hvem av foreldrene som får medhold i lagmannsrettene?

I 2015 vant den ankende part frem i spørsmålet om bosted i nesten en tredjedel av sakene. Det vil si at avgjørelsen fra tingretten ble omgjort. Når far anket, vant han frem i ni av de tretti sakene, og når mor anket, vant hun frem i ti av de tretti sakene. Man skal være forsiktig med å trekke konklusjoner på grunnlag av så små tall, men det bør kunne sies at både mødre og fedre som har tapt i tingretten, har muligheter for å vinne frem når saken står for lagmannsretten. I Hauglis undersøkelse fra 2002 fant hun lignende mønster. Bostedsdommene

\footnotetext{
${ }^{47}$ Samvær med beskyttet tilsyn kan fastsettes for inntil 16 timer i året, og den lokale barneverntjenesten skal føre tilsynet. $\varnothing$ vrige tilsynsformer etter barneloven er støttet og privat tilsyn. Når disse formene for tilsyn anvendes, er det andre forhold enn alvorlig svikt ved foreldrenes omsorgsevne som begrunner tilsynet.
} 
fra tingrettene ble omgjort i litt mer enn én av fem saker, omtrent like ofte i favør av far som i favør av mor. ${ }^{48}$

\section{Barnas alder, kjønn og antall barn i sakene}

Hvilken betydning har barnas alder for utfallet i sakene? Den følgende analysen tar utgangspunkt i alderen til det yngste barnet. ${ }^{49}$ I en fjerdedel av sakene var det yngste barnet under fem år, og retten fastsatte bosted hos henholdsvis mor eller far i omtrent like mange saker.$^{50}$ I litt over halvparten av sakene var det yngste barnet mellom fem og ti år. Her fikk mor omsorgen i litt over halvparten av sakene. I nesten én av fem saker var barna ti år eller eldre, og her fikk far omsorgen i tre fjerdedeler av sakene. Tendensen viser at far oftere får omsorgen for de eldste barna, mor oftere for barn mellom fem og ti år, og at de yngste barna ble fordelt likt mellom mor og far.

$\mathrm{Og}$ - hvordan slår barnas kjønn ut når det gjelder fordeling mellom mor og far? Holdes saken hvor det ble fastsatt delt bosted, og et par saker der barnets kjønn er uopplyst, utenfor, sitter vi igjen med 57 saker. De omfatter omtrent like mange gutter som jenter. I sakene som kun omfattet jenter, fikk mor omsorgen i nesten to tredjedeler av sakene.

Omvendt, i saker som kun omfattet gutter, fikk far omsorgen i to tredjedeler av sakene. I de få sakene der søsken hadde forskjellig kjønn, ble utfallet likt mellom mor og far.

Det neste spørsmålet er om antallet barn som omfattes i saken, kan ha noen betydning for utfallet. Sakene fra 2015 gjaldt bosted for 79 barn. I 45 saker handlet tvisten om ett barn. Her fikk mor omsorgen i 23 av sakene, og far i 22 saker. Videre handlet tvisten i 11 saker om 2 barn. Her fikk mor omsorgen i 6 saker, far i 4 saker, og i én sak ble det fastsatt delt bosted. Fire saker handlet om bosted for 3 søsken. Her fikk mor omsorgen i én sak, og far i 3 saker. Det ser dermed ikke ut til at antall barn som omfattes i sakene, utgjør noen merkbar forskjell i rettens vurderinger av bosted hos mor eller far.

\section{Avsluttende drøfting}

I lagmannsrettsdommene fra 2015 ble ikke foreldrenes kjønn eksplisitt vektlagt i

begrunnelsene for valg av bosted mellom mor og far. ${ }^{51}$ Analysen av argumenter som ble lagt til grunn for avgjørelsene, og fordeling av barn ut fra noen sentrale kjennetegn ved dommene,

\footnotetext{
${ }^{48}$ Haugli, T. (2007).

${ }^{49}$ Det manglet opplysninger om barns alder i én sak.

${ }^{50}$ I to av sakene hadde disse barna eldre søsken som var omfattet av saken. I resten sto tvisten om ett felles barn. Gitt tiden det tar fra samlivsbrudd til saken står for lagmannsrettene, var ingen av barna under to år. Mor fikk omsorgen i én sak mer enn far.

${ }^{51}$ Dybfest (2019) konkluderer også med at både foreldres og barnas kjønn ikke lenger er noe vektig argument i foreldretvister.
} 
viser at det likevel kan skjule seg noen kjønnede mønstre bak en jevn fordeling mellom mor og far. Når det gjelder argumentene som legges til grunn for utfallet i dommene, peker hensynet til risiko ved miljøskifte, barnas følelsesmessige tilknytning og hovedomsorg i samlivet seg ut som momenter som ofte vektlegges når mor får omsorgen. Hensynet til best samlet foreldrekontakt og stabilitet er momenter som oftere fører til utfall i favør av far. Tidligere undersøkelser viser samme tendens, og særlig hensynet til stabilitet har over tid vært et argument som ofte vektlegges når fedre får omsorgen. ${ }^{52}$ De kjønnede mønstre som fremtrer i denne analysen, er ikke ensbetydende med at dommerne tenker foreldrenes kjønn inn i momentene når de vurderer barnas beste. Tvert imot kan fedre vinne frem med argumentet om risiko ved miljøskifte, barnets følelsesmessige tilknytning og hovedomsorg i samlivet, når omstendighetene i deres sak taler for det. Omvendt kan også mødre vinne frem med argumentene om best samlet foreldrekontakt og hensynet til stabilitet. Kjønnede mønstre som spores i analysen, kan derfor også være et resultat av kjønnsnøytrale vurderinger.

I de sakene hvor barnet hadde fremsatt et ønske om bosted enten hos mor eller far, var det samsvar mellom barnets $\emptyset$ nske og utfallet i de fleste sakene. Barnas $\emptyset$ nsker fordelte seg jevnt mellom bosted hos fedre eller mødre, og i de få sakene der utfallet gikk mot barnas $\emptyset n s k e r$, ble utfallet like ofte bosted hos far som hos mor. Med økt vektlegging av barnets $\emptyset n$ ske de senere årene er dette utvilsomt et moment som kan påvirke utfall i foreldretvister. Med den jevne fordelingen av barn som ønsket å bo henholdsvis hos mor eller far, ser det ut til at barnas ønsker har bidratt til jevn fordeling av fast bosted mellom far og mor i 2015. Videre har vi sett at foreldrenes personlige egenskaper like ofte talte i favør av bosted hos far som hos mor. Dette momentet støtter dermed også opp under det jevne utfallet i sakene.

I sum førte argumentasjonen i dommene fra 2015 til et jevnt utfall mellom mor og far. For noen momenter var det ikke mulig å spore kjønnede mønstre. Andre momenter pekte seg ut enten i favør av mor eller far. Når utfallet ble jevn fordeling, kan vi konkludere med at disse kjønnede mønstrene nullet hverandre ut.

Analysen av kjennetegn ved sakene gir et lignende inntrykk som argumentanalysen. Noen kjennetegn viser kjønnede mønstre i fordeling, andre ikke. Ved å løfte frem spørsmålet om hvem som anket saken, har vi fått belyst dommernes vurderinger av foreldrenes omsorgssituasjon for to rettsinstanser. I sakene i 2015 var fedre like ofte som mødre den ankende part. Tingrettene hadde dermed vurdert at fedre like ofte som mødre kunne tilby den beste omsorgsløsningen for barna i disse sakene som ble anket. Lagmannsrettene kom til et

\footnotetext{
${ }^{52}$ Skjørten, K. (2005); Haugli, T. (2007).
} 
annet resultat enn tingrettene i en tredjedel av sakene, men også her viste det seg at fedre vant frem omtrent like ofte som mødre. Sammenholdes dette med funnene fra analysen av foreldres personlige egenskaper, hvor momentet like ofte gikk i favør av far som i favør av mor, svekker dette påstanden om at bare fedre som stiller spesielt sterkt som omsorgspersoner, har mulighet for å vinne frem i lagmannsrettene.

Antallet barn som er omfattet i saken, avdekker ingen kjønnede dimensjoner i rettens vurderinger. Når det gjelder barnas alder, var det jevn fordeling mellom mor og far for de barna som var under fem år, og foreldrenes kjønn inngikk ikke som argument for utfall i disse sakene. Som nevnt ble morspresumsjonen fjernet med barneloven av 1981, og jeg fant ikke tegn på at den tidligere normen om mødres fortrinnsrett til de yngste barna er virksom, verken i de angitte begrunnelsene for utfall eller i det skjulte for dommene fra 2015. Denne konklusjonen støttes også av tidligere undersøkelser. ${ }^{53}$ Dybfest fant imidlertid i sin gjennomgang av lagmannsrettsdommer fra 2017 og 2018 en skjevdeling av barn under syv år i favør av mor. For barna fra syv år og oppover var fordelingen lik mellom far og mor. Dybfest forklarer skjevdelingen av de yngste barna med at mødrene oftest har hatt hovedomsorg for barna i samlivet. ${ }^{54}$ I min unders $\varnothing$ kelse ble momentet om miljøskifte sammenstilt med andre momenter som barnets tilknytning, foreldrenes personlige egenskaper, stabilitet og best samlet foreldrekontakt oftest lagt til grunn for utfall når det gjaldt de yngste barna. I noen av sakene ble også hovedomsorg i samlivet trukket frem i favør av mor, men aldri som eneste begrunnelse for avgjørelsen. Fra en av partene reiser sak for domstolene, til saken behandles i lagmannsrettene, kan det gå ganske lang tid. De yngste barna i min undersøkelse var to år. I flere av sakene hvor far fikk omsorgen, ble utfallet begrunnet med risiko for miljøskifte. Disse barna bodde på tidspunktet for lagmannsrettsbehandlingen fast hos far. Hvem av partene som har hatt hovedomsorg i samlivet, svekkes som moment jo lengre tid som er gått siden samlivsbruddet, og skifter hovedomsorgen fra den ene parten til den andre etter brudd, blir vekten av momentet vesentlig redusert. Om nåværende omsorgssituasjon er tilfredsstillende, anvendes ofte status quo-argumentet, hvor retten viser til at flytting av bosted må innebære en fordel for barnet. Hvem som har hovedomsorgen etter samlivsbrudd, kan dermed gis større vekt enn hvordan omsorgen ble fordelt i samlivet.

Det var flest saker med barn i aldersgruppen fem til ti år. Her ble utfallet litt oftere i favør av mor enn i favør av far. Videre viste det seg at flesteparten av barna i den eldste aldersgruppen fikk fast bosted hos far. Samtidig har barnas egne $\emptyset$ nsker om bosted større vekt

\footnotetext{
${ }^{53}$ Sandberg, K. (1990); Skjørten, K. (2005).

${ }^{54}$ Dybfest, H.E. (2019).
} 
i avgjørelsene som angår de eldste barna, og et flertall av disse hadde uttrykt at de ønsket bosted hos far.

Når det gjelder barnas kjønn, fikk fedre oftere får omsorgen for gutter, og mødre oftere omsorgen for jenter. Dette er overraskende, fordi jeg ikke fant spor av argumentasjon fra rettens side i retning av at gutter har best av å vokse opp med fedre, og jenter med mødre. Spørsmålet blir om det bak dette kjønnede mønsteret skjuler seg kjønnede vurderinger fra dommernes side, forstått som en tilbøyelighet til at far får omsorgen for gutter, og mor for jenter. Om dette er tilfellet, kan det bety at det tidligere momentet som kjønnsidentifikasjon som kunne legges til grunn i saker der retten fant at gutter burde vokse opp hos far og jenter hos mor, lever videre i det skjulte. Samtidig kan denne skjeve fordelingen av barna etter kjønn også være basert på andre forhold, som i sum gjør at dette kun er et tilfeldig og uinteressant funn. For å nærme meg et svar på dette gikk jeg tilbake til dommene fra 2012 for å se hvordan utfallet ble der i forhold til foreldrenes og barnas kjønn. Her viste det seg at både gutter og jenter ble tilnærmet likt fordelt mellom mødre og fedre. Dette $\varnothing$ ker sannsynligheten for at det er andre momenter enn barnets kjønn som har vært utslagsgivende for utfall i 2015.

Vi har sett at utfallet i foreldretvister for lagmannsrettene over tid ikke tyder på vesentlige skjevheter i fordeling av barn mellom mor og far. Det er likevel verdt å merke seg variasjoner i favør av mor eller far som fremkommer i noen av de tidsperiodene der vi har kunnskap om utfall. Mine og andres unders $\varnothing$ kelser dekker omtrent halvparten av tidsspennet fra 1998 til 2018. Hadde vi hatt data fra hele denne tidsperioden, ville kanskje bildet sett noe annerledes ut. Om utfallet i større grad ville gått i favør av mor eller far, er ikke godt å si. Det vil imidlertid være oppsiktsvekkende og kanskje urovekkende om det skulle vist seg at barn ble tilnærmet likt fordeling i hele denne perioden. Det er jo ikke rettferdig fordeling mellom foreldre som er rettens anliggende, men en konkret vurdering av barnets beste i den enkelte sak. Vi mangler foreløpig kunnskap om hvordan utfallet av foreldretvister om bosted ser ut for de samlede tingretter. En eldre undersøkelse fra Oslo tingrett fant en skjevdeling i favør av mor. ${ }^{55}$ Om dette viser seg å være gjennomgående på tingrettsnivå i dag, bør det undersøkes nærmere hva som ligger bak. Budskapet fra denne gjennomgangen av dommer fra lagmannsrettene er likevel at om det ikke hefter alvorlige mangler ved foreldrenes omsorgssituasjon, har både fedre og mødre mulighet til å nå frem med krav om bosted for barna når saken står for lagmannsrettene.

\footnotetext{
${ }^{55}$ Koch, K. (2000), Når mor og far møtes i retten - barnefordeling og samvær, NOVA, Rapport 13/2000.
} 